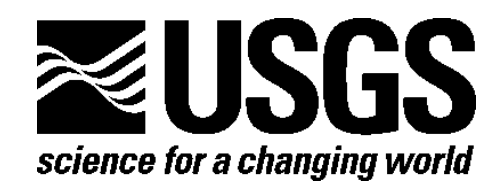

Western Fisheries Research Center, Columbia River Research Laboratory

\title{
Monitoring of Stream Restoration Habitat on the Main Stem of the Methow River, Washington, During the Pre-Treatment Phase (October 2008-May 2012) with a Progress Report for Activities from March 2011 to November 2011
}

By Wesley T. Tibbits, Kyle D. Martens, and Patrick J. Connolly

Open-File Report 2012-1108

U.S. Department of the Interior

U.S. Geological Survey 


\section{U.S. Department of the Interior \\ KEN SALAZAR, Secretary}

\section{U.S. Geological Survey \\ Marcia K. McNutt, Director}

U.S. Geological Survey, Reston, Virginia: 2012

For more information on the USGS—-the Federal source for science about the Earth, its natural and living resources, natural hazards, and the environment, visit http://www.usgs.gov or call 1-888-ASK-USGS.

For an overview of USGS information products, including maps, imagery, and publications, visit http://www.usgs.gov/pubprod

To order this and other USGS information products, visit http://store.usgs.gov

Suggested citation:

Tibbits, W.T., Martens, K.D., and Connolly, P.J., 2012, Monitoring of stream restoration habitat on the main stem of the Methow River, Washington, during the pre-treatment phase (October 2008-May 2012) with a progress report for activities from March 2011 to November 2011: U.S. Geological Survey Open-File Report 2012-1108, 16 p.

Any use of trade, product, or firm names is for descriptive purposes only and does not imply endorsement by the U.S. Government.

Although this report is in the public domain, permission must be secured from the individual copyright owners to reproduce any copyrighted material contained within this report. 


\section{Contents}

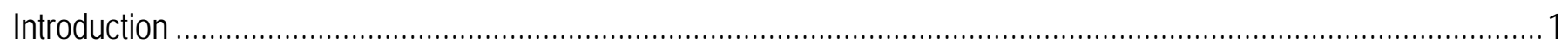

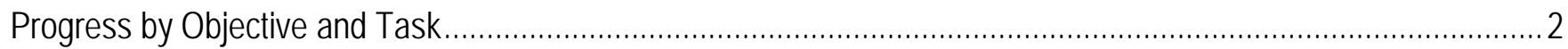

A: Determining the importance of connectivity to fish production: downstream, upstream, and lateral................. 2

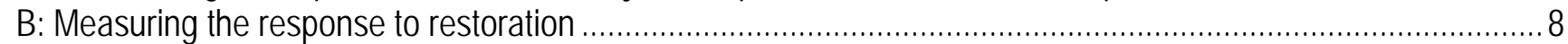

C: Modeling the potential fish response to restoration ............................................................................

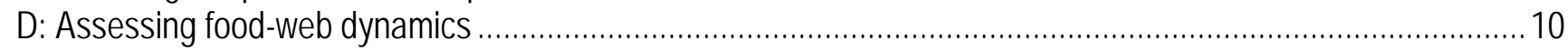

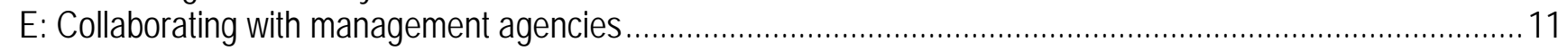

\section{Figures}

Figure 1. Map of the M2 Reach with PIT tag interrogators installed and maintained by USGS

as of November 2011

Figure 2. Map of study area in the Methow River with PIT tag interrogators installed and maintained

by the USGS as of November 2011 .

\section{Tables}

Table 1. Streams surveyed for fish and where a total of 5,935 PIT tags were deployed in the Methow watershed during the 2011 field season .....

Table 2. Presence and absence of fish species sampled and/or observed in the Methow watershed by the U.S. Geological Survey during the 2011 field season....

Table 3. Streams surveyed or sampled for fish and where a total of 2,101 genetic samples collected in the Methow watershed during the 2011 field season.... 15

Table 4. Current status of USGS temperature loggers in the Methow River and its tributaries 


\section{Conversion Factors}

\begin{tabular}{lll}
\hline \multicolumn{1}{c}{ Multiply } & \multicolumn{1}{c}{ By } & \multicolumn{1}{c}{ To obtain } \\
\hline centimeter $(\mathrm{cm})$ & 0.3937 & inch (in.) \\
$\begin{array}{l}\text { cubic foot per second per square mile } \\
{\left[\left(\mathrm{ft}^{3} / \mathrm{s}\right) \mathrm{mi}^{2}\right]}\end{array}$ & 0.01093 & $\begin{array}{l}\text { cubic meter per second per square } \\
\text { kilometer }\left[\left(\mathrm{m}^{3} / \mathrm{s}\right) / \mathrm{km}^{2}\right]\end{array}$ \\
millimeter $(\mathrm{mm})$ & 0.03937 & inch (in.) \\
meter $(\mathrm{m})$ & 3.281 & foot (ft) \\
kilometer $(\mathrm{km})$ & 0.6214 & mile (mi) \\
meter $(\mathrm{m})$ & 1.094 & yard (yd) \\
\hline
\end{tabular}

Temperature in degrees Celsius $\left({ }^{\circ} \mathrm{C}\right)$ may be converted to degrees Fahrenheit $\left({ }^{\circ} \mathrm{F}\right)$ as follows:

${ }^{\circ} \mathrm{F}=\left(1.8 \mathrm{x}^{\circ} \mathrm{C}\right)+32$. 


\title{
Monitoring of Stream Restoration Habitat on the Main Stem of the Methow River, Washington, During the Pre-Treatment Phase (October 2008-May 2012) with a Progress Report for Activities from March 2011 to November 2011
}

\author{
By Wesley T. Tibbits, Kyle D. Martens, and Patrick J. Connolly
}

\section{Introduction}

The U.S. Geological Survey (USGS) received a request from the Bureau of Reclamation (Reclamation) to provide monitoring and an evaluation of the effectiveness of habitat actions that Reclamation plans to implement in the Upper Columbia River basin, which includes the Methow River. This monitoring and evaluation program is to partially fulfill Reclamations part of the 2008 Biological Opinion for the Federal Columbia River Power System that includes a Reasonable and Prudent Alternative (RPA) to protect listed salmon and steelhead across their life cycle. The target species in the Methow River for this monitoring and restoration effort include Upper Columbia River (UCR) spring Chinook salmon (Oncorhynchus tshawytscha), UCR steelhead (O. mykiss), and bull trout (Salvelinus confluentus), which are listed as threatened or endangered under the Endangered Species Act.

This report covers UCR activities performed by USGS personnel from March 2011 to November 2011. It involves collecting and analyzing data collected during pre-implementation (2008-2012) there will be a follow-up after actions are completed (2012-2014). The goal of Reclamation is to maximize the potential of habitat and improve proposed limiting factors affecting the middle Methow River subwatershed (Reclamation, 2010). The Middle Methow (M2) reach (river kilometer mile [rkm] 843.065 to 843.080) of the Methow River was selected as the treatment reach for this study based on possible stream restoration plans by Reclamation (fig. 1). The upper Methow River (rkm 843.094 and 843.080), Chewuch River, and the Methow River downstream of the Twisp River (rkm 843.065) are being sampled as reference and control reaches in this study (fig. 2). This report covers the third year in the preevaluation of the M2 reach and its side channels. Restoration of the M2 reach is scheduled for 2012, which is planned to be followed by a multi-year intensive post-evaluation period.

The intent of the summary of information provided in this report is to fulfill the objectives and tasks submitted in a statement of work to Reclamation in November 2010 (Connolly and Martens, 2011). The study design provides data by which to assess potential fish response to a Reclamation habitat restoration effort focused to improve juvenile salmonid rearing habitat in the M2, which runs between the towns of Winthrop and Twisp, Washington (fig. 1). The pre-treatment phase of the study is designed so that specific questions about the response of target fish species (spring Chinook salmon, steelhead, and bull trout) to the restoration actions can be addressed. Effectiveness is being determined by measuring fish productivity and habitat connectivity of the restoration reach and adjoining reaches, and their tributaries. The study includes sampling efforts directed to understand the relationships between stream habitat and the abundance of various fish species and to assess the response of the fish community. To complement these measurements, we will use models to predict response to treatment, and we will update the model 
with empirically derived data as these data become available. This modeling effort is expected to inform us of data gaps, sensitivity of key variables, and ability to detect response based on variability of the data.

The approach and actions taken or planned by Reclamation to modify off-channel habitat are largely untested as to their effectiveness to improve target fish species' productivity and survival needs. Those documented strategies that identify both physical parameters and biological relationships and benefits have been identified (Reclamation, 2008). To assess biological performance, we plan to compare age structure, growth, and age at smolting between those fish that stay in natal areas versus those fish that move. To assess retention in, and movement from or into, the restoration reach, we have used a combination of within-reach and out-of-reach sampling. We are using passive integrated transponder (PIT) tags, a network of instream PIT tag interrogation systems, and smolt traps to assess differences in biological performance and the magnitude of retention in, and movement from and into, the restoration reach.

\section{Progress by Objective and Task}

A. Determining the importance of connectivity to fish production: downstream, upstream, and laterally

Objective 1. Assess productivity and connectivity of the restoration reach and neighboring reaches, and their tributaries, with emphasis on target fish species Chinook salmon, steelhead, and bull trout.

Task 1.1 (updated plan for 2011 and 2012). Conduct fish snorkeling surveys at established sections in the restoration, reference, and control reaches multiple times within the year.

Progress in 2011: We completed electronic data entry for data collected in 2010. Snorkel surveys were conducted at each of our four side channel (population estimates) sites in the M2 (fig. 2). Snorkel sites are located in the mainstem Methow River on the outside bend of each side channel. We used an upstream survey protocol, twice in August, once in September, and once in November. All surveys were completed in one day. A combination of snorkel surveys and a quantitative electrofishing effort will provide a fish assemblage and density estimates for these sites. Snorkel data entry and analysis have been initiated.

Task 1.2 (updated plan for 2011 and 2012). Conduct point-abundance surveys at fixed sites by electrofishing in the restoration, reference, and control reaches multiple times within the year.

Progress in 2011: We completed electronic data entry for data collected in 2010. Point-abundance surveys were conducted at the same four sites as the new M2 snorkel survey sites described above. Point-abundance surveys were conducted one time in July. We sampled each site in an upstream direction by bank-unit type, and all sites were completed in one day. Data entry and analysis have been initiated.

Task 1.3 (updated plan for 2011 and 2012). Conduct mark-recapture and/or pass-removal electrofishing surveys to derive fish assemblage, abundance, and density estimates in 10 side channels at multiple times per year, including the side channels chosen for installation of PIT tag interrogation systems (see Task 1.5). 
Progress in 2011: We completed electronic data entry for data collected in 2010. Population estimates were determined in the same 10 side channels sampled in 2010. These sites include the four side channels in the M2 reach, three side channels in the upper Methow, two side channels in the Chewuch River, and one side channel in the M3 reach, aka "Silver Reach," just downstream of the M2 reach. Population estimates were measured for each side channel in March, August, and September/October. In habitat units too deep for multiple pass-removals, mark-recapture and or snorkel estimates were used to determine these fish assemblage, abundance, and density estimates. Habitat units with high salmon or steelhead redd densities were not sampled. Data entry and analysis have been initiated.

Task 1.4 (updated plan for 2011 and 2012). Conduct mark-recapture and/or pass-removal electrofishing surveys to derive fish assemblage, abundance, and density estimates in a 500-m section of Wolf Creek, Eightmile Creek, and in two reaches of Beaver Creek.

Progress in 2011: We completed electronic data entry for data collected in 2010. We conducted multiple pass-removal estimates at our index sites for Wolf Creek and two index sites in Beaver Creek. Due to high water and debris in the fall, we could not derive fish abundance estimates for the Eightmile Creek index site. Data entry and analysis have been initiated.

Task 1.5 (updated plan for 2011 and 2012). Maintain and assess efficiency of three multiplexing PIT tag interrogation sites formerly installed in the upper Methow, Chewuch, and M2 sites in 20112012.

Progress in 2011: We completed electronic data entry for data collected in 2010. High-water damage required that we rebuild and reinstall parts of the Chewuch and upper Methow interrogators. The interrogator in the Methow River upstream of the Twisp River was not reinstalled after high water (June). We tested the detection efficiency at each site in the spring of 2011 by releasing groups of PIT-tagged age-2 steelhead smolts from the U.S. Fish and Wildlife Service's Winthrop National Fish Hatchery. We released 400 fish above the upper Methow, middle Methow, and lower Methow interrogators once in low flow (300-500 cubic feet per second [cfs]) and a second 400 fish at each site in high flow (>3,000 cfs). All sites are registered with PTAGIS and all data from these sites are uploaded on a weekly basis.

Task 1.6 (updated plan for 2011 and 2012). Maintain five single-antenna PIT tag interrogation systems in four side channels, and add additional single-antenna systems when feasible.

Progress in 2011: We completed electronic data entry for data collected in 2010. We continued to run three single-antenna PIT tag interrogators in two side channels in the M2 reach and two in side channels in the upper Methow. We replaced damaged antennas from 2010 in the spring of 2011. These sites were revisited after high water in spring 2011, and replacements were made in two of the three channels in the middle Methow and two of the side channels in the upper Methow. Disconnection of side channels from the M2, due to low flow, disrupted PIT tag interrogation at these sites for the duration of the year. 
Task 1.7 (updated plan for 2011 and 2012). Maintain seven single-antenna PIT tag interrogation systems in Methow tributaries: one in lower Libby Creek, one in lower Gold Creek, two in Beaver Creek, two in Eightmile Creek, and one in Wolf Creek.

Progress in 2011: We completed electronic data entry for data collected in 2010. PIT tag interrogation systems were maintained in 2011. Sites were visited one to two times a week to change batteries, maintain solar power, and download interrogators. In late spring most interrogation sites were lost due to high water. Sites replaced after high water in spring 2011 include lower Eightmile Creek, lower Libby Creek, upper Beaver Creek, and Wolf Creek. Currently, we have interrogation sites operating in Wolf Creek, Beaver Creek, Libby Creek, and upper Eightmile Creek. Data were uploaded monthly to the PTAGIS website.

Task 1.8 (updated plan for 2011 and 2012). Install and run a rotary screw trap in the Chewuch River upstream and near its confluence with the Methow River.

Progress in 2011: We completed electronic data entry for data collected in 2010. A rotary screw trap was installed in the Chewuch River on March 15, 2011. The trap was attached to the Highway 20 Bridge in the town of Winthrop, Washington (fig. 2) and checked daily until May 5, 2011, when it was removed due to high water. The trap was redeployed on July 27, 2011, and ran Monday through Friday of each week until November 9, 2011, when the trap was removed due to low fish numbers and potential ice buildup on the trap. We sampled 3,046 fish at the trap in 2011. A total of 1,911 fish were PIT tagged; of these were 325 rainbow trout/steelhead, 14 westslope cutthroat, 1,304 spring Chinook, 1 coho, 8 bridgelip suckers, 29 mountain whitefish, and 231 longnose dace (table 1). Capture efficiencies were determined for naturally spawned spring Chinook at low flows (200-400 cfs). Due to few juvenile steelheads being captured and an early spring high flow, we were not able to produce estimates for summer steelhead smolts in 2011. We plan to collaborate with the Washington State Department of Fish and Wildlife (WDFW) and Yakama Nation (YN) in 2012 in hopes of improving these capture efficiency estimates.

Task 1.9 (updated plan for 2011 and 2012). Insert PIT tags in fish caught during electrofishing (see Tasks1.2-1.4), smolt trapping (see Task 1.8), or other means (for example, seining, angling, and snetting).

Progress in 2011: We completed electronic data entry for data collected in 2010. PIT tags were distributed from March 17, 2011, through November 9, 2011, in the Methow watershed. A total of 5,935 fish were PIT tagged in the Methow watershed during the 2011 field season (table 1). Of these, 2,861 tags were deployed in the mainstem Methow, and 2,389 were deployed in the Chewuch drainage. The majority of these tags went in spring Chinook and rainbow trout/steelhead. PIT tag data were entered and uploaded into the PTAGIS database.

Task 1.10 (updated plan for 2011 and 2012). Mark targeted fish species collected in the upper Methow River (reference reach) and Chewuch River that are too small to PIT tag with 8-mm tags with visible implant elastomer (VIE) tags.

Progress in 2011: We completed electronic data entry for data collected in 2010. No fish were tagged with VIE tags in 2011 due to low recapture rates. 
Task 1.11 (updated plan for 2011 and 2012). Collect and store tissue samples (such as fin clips) for genetic analysis from a subsample of naturally produced steelhead and Chinook salmon collected during fish sampling efforts associated with other tasks.

Progress in 2011: We completed electronic data entry for data collected in 2010. Fin clips were taken on 2,101 fish for genetic analysis in 2011. Samples were taken mainly from Chinook and rainbow/steelhead. A total of 1,023 rainbow/steelhead, 816 Chinook salmon, 220 coho, 29 westslope cutthroat, and 13 bull trout (table 2). Data analysis has not been completed.

Task 1.12 (updated plan for 2011 and 2012). Collect and archive otoliths from fish mortalities encountered during fish sampling efforts associated with other tasks.

Progress in 2011: We completed electronic data entry for data collected in 2010. Otoliths were taken from 15 mountain whitefish in the lower Methow River (rkm 843.060).

Task 1.13 (updated plan for 2011 and 2012). Collaborate and assist Reclamation with effort to maintain thermographs throughout the Methow watershed and to manage the data.

Progress in 2011: We completed electronic data entry for data collected in 2010 (table 3). We assisted Reclamation to deploy a total of 28 Hobo Onset V2 temperature loggers to record temperature every 30 minutes. In April 2011, we retrieved 25 of the loggers from the field to download the data. Three loggers (Upper Beaver Creek-Reach 4, Eightmile Creek at Flat Campground, and Gold Creek below Foggy Dew Creek) were inaccessible due to snow and ice. Prior to redeployment, all temperature loggers underwent an accuracy check as outlined in the temperature monitoring section in the Water Quality Monitoring Technical Guide Book: Oregon Plan for Salmon and Watershed (Water Quality Monitoring Technical Guide Book, 1999). Currently, 29 temperature loggers are deployed.

Task 1.14 (new). Assess physical habitat of side channels at different flow levels.

Progress in 2011: We completed electronic data entry for data collected in 2010. We conducted habitat surveys in side channels during periods of variable flows in spring and early summer. Surveys were measured against USGS mainstem flow gages. Data entry and analysis have been initiated.

Task 1.15 (new). Conduct habitat surveys of stream margins and banks in the M2 and M3 reaches.

Progress in 2011: Habitat of the stream margins and banks in the M2 and M3 reaches were surveyed in summer 2011 by U.S. Forest Service personnel as part of a collaborative effort with Reclamation and USGS. USGS personnel helped primarily with survey design and implementation. Data entry and analysis have been initiated. 
Task 1.16 (new). Assess predation of fall Chinook eggs by other fish species.

Progress in 2010-2011: In 2010, underwater cameras were used to record summer Chinook redds and to the assess degree of egg predation that may have occurred. Video recordings did not show direct egg consumption. On two separate dates, a bull trout ( $\sim 300 \mathrm{~mm}$ total length) was videotaped downstream of a salmon redd. Diet samples of fish in the area caught by hook and line showed three species of fish feeding on salmon eggs: bull trout, cutthroat trout, and rainbow trout. We completed electronic data entry for data collected in 2010. No fish samples or underwater video were collected in 2011.

\section{B. Measuring the response to restoration}

\section{Objective 2. Assess changes in fish population metrics as a result of stream restoration actions in the treatment reach.}

Task 2.1. Assess changes in the following metrics for steelhead and spring Chinook between pretreatment and post-treatment periods in the treatment, reference, and control reaches: Smolt age structure, annual and seasonal growth of parr (length, mass), parr-to-parr survival, parrto-smolt survival, smolt-to-adult survival, degree of retention of fish natal to the treatment reach, degree of retention of fish not natal to the treatment reach, number of smolts produced (from natal fish, and from non-natal fish temporally retained), residualism of natal and nonnatal wild steelhead, and residualism of hatchery released steelhead (which could be related to habitat availability and/or hatchery practices).

Progress in 2011: Intensive fish collection and PIT tagging were conducted during the 2009, 2010, and 2011 field seasons. Combined with the installation of several PIT tag interrogators, these efforts will form the backbone for this analysis. Analysis of fish behavior has been initiated.

Task 2.2. Assess changes in the following metrics for individual species and/or the multiple species within the fish community between pre-treatment and post-treatment periods in the treatment, reference, and control reaches:

Fish species presence or absence

Relative abundance of fish within the assemblage

Relative abundance, size, and/or age structure of competitors (for example, mountain whitefish, brook trout, and sculpin)

Relative abundance, size, and/or age structure of predators (for example, bull trout)

Progress in 2011: Data entry was completed and some analysis has been completed. We collected pretreatment data on fish presence and absence (table 4), relative abundance, and age structure of competitors and predators in tributaries and side channels to the Methow River.

Task 2.3. Determine if there was a change in nutrient production and/or nutrient retention between pretreatment and post-treatment periods in the restoration reach.

Progress in 2011: Data entry was completed and some analysis has been completed. No data for this task were collected in 2011. 


\section{Modeling the potential fish response to restoration}

Objective 3. Develop a reach-based fish production model to incorporate the dynamics and capacity of anadromous salmonids in the Methow watershed, with the ability to assess the role of fish movement and habitat connectivity and to assess the potential effectiveness of restoration actions.

Task 3.1. Model major aspects of population dynamics (fish growth, survival), life history strategies (movement, age at smolting, age at adult return), and species interactions (competition, predation) to gauge the potential response of target fish species (Chinook, steelhead, bull trout) and other fish species (rainbow trout, cutthroat trout, mountain whitefish, dace, sculpin, and others) to the restoration effort.

Progress in 2011: Modeling efforts included adjustments and refinements of Patrick J. Connolly’s (unpublished) deterministic life history model for steelhead, and using the model to test various hypotheses about changes in survival and smolt age. In addition, much collaborative effort was expended to provide data and life history information for a related but distinct modeling effort being conducted by USGS and Reclamation personnel (funded by Reclamation).

Task 3.2. Collaborate in ongoing efforts with other agencies, universities, private entities, and tribes to assess primary driver variables and to derive pertinent models that describe fish and habitat relationships and that estimate productivity. Progress in 2011: Much collaboration was done with many entities, including: Reclamation, U.S. Fish and Wildlife Service (USFWS), U.S. Forrest Service (USFS), Yakama Nation, Washington Department of Fish and Wildlife, Methow Salmon Recovery Foundation (MSRF), and Wild Fish Conservatory. Collaboration efforts with agencies and private organizations resulted in much sharing of data and field personal.

\section{Assessing food-web dynamics}

Objective 4. Assess the current food web and potential for biotic resistance imparted by presence and abundance of other interacting fish (for example, native, nonnative, hatchery releases) and other members of the aquatic community (for example, predators, competitors) in the restoration and potentially connected reaches in the mainstem Methow and Chewuch Rivers based on aquatic productivity and fish diet information.

Task 4.1. Assess productivity and food web dynamics in the restoration reach.

Progress in 2011: This work was conducted by doctoral student J. Ryan Bellmore of Idaho State University (ISU). The goal of this work is to construct a quantitative food web for the fish assemblage in the restoration reach of the Methow River. This analysis will help determine both the potential for food limitation in the restoration reach of the Methow and the potential for competition among species in the fish assemblage. To construct this food web, Bellmore is estimating the total invertebrate food base available to fish, and the annual production of fish. To estimate the invertebrate food base, seasonal samples (four sampling dates) of aquatic invertebrates have been taken in both the main channel and five side channels of the Methow River. In addition, at two sites (the main channel and one side channel) monthly samples were taken to quantify the growth of individual invertebrates ( $n=12$ samples from each site). Together these samples will be used to calculate annual aquatic invertebrate production for the 
restoration reach. In addition, the input of terrestrial invertebrates, which can be an important part of the diet of many salmonid fishes, was sampled three times during the summer of 2009. The portion of the food base available to fish is being determined via fish diet and isotope samples taken from the dominant fish species present in the main channel and each of the five side channel sites ( $n=$ approximately 600 samples). By November 2009, all the field data had been collected for this study (including fish surveys conducted in cooperation with the USGS). By summer 2011, Dr. Bellmore completed his dissertation.

Task 4.2. Collaborate with and assist the Yakama Nation in its effort to assess the effects of added nutrients to portions of the Methow subbasin.

Progress in 2011: Several meetings were held with John Jorgensen of the Yakama Nation (lead for the nutrient project), including some field reconnaissance.

E. Collaborating with management agencies

Objective 5. Collaborate with and participate in a multi-agency effort to develop and implement a coordinated inter-agency basin-wide research and monitoring program for the Methow River. Use efforts underway by other agencies to supplement project activities to further tasks and objectives included in this agreement.

Task 5.1. Collaborate with WDFW, USFS, and YN to help ensure that systematic redd surveys in the potentially connected reaches in the mainstem Methow and Chewuch Rivers are conducted throughout spawning times of Chinook, steelhead, coho, and bull trout.

Task 5.2. Collaborate with WDFW to help ensure their planned smolt trapping, PIT tagging, and deployment of PIT tag interrogation systems are conducted during March-November at the specified sites in the Twisp River and the mainstem Methow River near McFarland Creek.

Task 5.3. Collaborate with and provide technical assistance to Reclamation (for example, Multiple Pathways and Indicator [MPI] surveys), USFS, YN, and other agencies and entities to ensure appropriate habitat variables for understanding fish-habitat relationships are being taken in the restoration reach, in control and reference reaches, and in selected side channels.

Task 5.4. Coordinate and share resources with other projects that monitor the status and trends of listed salmon, steelhead, and bull trout in the basin. These agencies and entities include the USFWS, NMFS, WDFW, YN, Bonneville Power Administration (BPA), and Upper Columbia Regional Technical Team (UCRTT).

Task 5.5. Coordinate and share resources with other agencies or projects that would provide data related to relative reproductive success of hatchery and naturally produced anadromous fish in the Methow subbasin.

Task 5.6. Coordinate and provide expertise as needed to further scientific equipment necessary to accomplish a pre-treatment restoration reach-based study. These activities would include identifying potential cost-share partners and technical expertise for PIT tag detector sites that would support the experimental design for this study. 
Task 5.7. Coordinate and provide expertise as needed to further scientific data and samples necessary for genetic information related to assessing the reproductive success of listed fish in the basin.

Task 5.8. Give technical presentations related to the project activities at Columbia Basin effectiveness monitoring meetings, interagency workgroups, watershed councils, landowner coordination meetings, and other appropriate scientific and public outreach forums.

Progress for 2011 (Tasks 5.1 - 5.8): Lists of all products, presentations, and posters for the duration of the Reclamation-funded USGS effort in the Methow watershed are provided below. In addition, multiple informal presentations and updates were given at local watershed and workgroup meetings and during field trips.

Products to Date

Mainstem Methow Project

Barber, J.J., K.G. Gerow, P.J. Connolly, and S. Singh. 2011. Estimating the proportion of hatchery fish that stray or residualize: A Bayesian approach. North American Journal of Fisheries Management 31:934-942.

Bellmore, J.R. 2011. The ecological importance of floodplains in montane river networks: Implications for habitat restoration and salmon recovery. Doctoral Dissertation, Department of Biological Sciences, Idaho State University, Pocatello, Idaho. (P.J. Connolly served on his Graduate Committee.)

Connolly, Patrick J., and Kyle D. Martens. 2010. Mainstem Methow habitat effectiveness monitoring of stream restoration: Study Plan update for FY2011 and FY2012. Background, Questions, Assumptions, Hypotheses, Objectives, and Tasks updated for 2010. Prepared for Bureau of Reclamation, Boise, Idaho. Connolly, P.J. 2010. Guidelines for calculating and enhancing detection efficiency of PIT tag interrogation systems. Chapter 7; Pages 119-125 in K.S. Wolf and J.S. O’Neal, editors. Tagging, Telemetry and Marking Measures for Monitoring Fish Populations-A compendium of new and recent science for use in informing technique and decision modalities. Pacific Northwest Aquatic Monitoring Partnership Special Publication 2010-002. http://www.pnamp.org/node/2871 (accessed January 5, 2011).

Lower Tributaries of the Methow Project

Martens, K.D., and P.J. Connolly. 2010. Effectiveness of a redesigned water diversion using rock vortex weirs to enhance longitudinal connectivity for small salmonids. North American Journal of Fisheries Management 30:1544-1552. http://afsjournals.org/doi/abs/10.1577/M10-025.1 (accessed January 6, 2011).

Connolly, P.J., K.D. Martens, D.E. Weigel, and W.T. Tibbits. 2010. Effectiveness of actions in Beaver Creek. Pages 54-57 in M.B. Ward, J. Morgan, and C. Baldwin, editors. Upper Columbia Regional Technical Team 2010 analysis workshop synthesis report. UCRTT and Terraqua, Inc., Wenatchee, Washington. http://www.ucsrb.com/Editor/assets/ucrtt\%202010\%20synthesis\%20report.pdf (accessed January 6, 2011)

Connolly, P.J., I.G. Jezorek, K. Martens, and E.F. Prentice. 2008. Measuring performance of two stationary interrogation systems for detecting downstream and upstream movement of PIT-tagged salmonids. North American Journal of Fisheries Management 28:402-417. http://afsjournals.org/doi/pdf/10.1577/M07-008.1 (accessed January 5. 2011)

Martens, K.D., and P.J. Connolly. 2008. Lower Methow tributaries intensive effectiveness monitoring study. Interim Report. Prepared for: Bureau of Reclamation, Portland, Oregon. 
Ruttenberg, D. 2007. An evaluation of fish passage at rock vortex weirs. M.S. Thesis. College of Engineering, University of Idaho-Boise. (P.J. Connolly served on his Graduate Committee.)

Martens, K., P.J. Connolly, D. Ruttenberg, and S. Clayton. 2006. Lower Methow tributaries intensive effectiveness monitoring study. Progress Report. Prepared for: Bureau of Reclamation, Portland, Oregon.

Presentations to Date

Connolly, Patrick J., Kyle D. Martens, and Dana Weigel. Efforts to reinvoke the steelhead life history in Beaver Creek: Will barrier removal alone suffice? For Symposium: Colonization and introduction of anadromous salmonids. American Fisheries Society National Meetings. August 2011, Seattle, Washington.

Connolly, Patrick J. Residualization and maturation versus smolting factors for O. mykiss parr. Conference and Workshop on Age and Maturity of Chinook Salmon and other Pacific Salmonids. May 2011, Portland, Oregon.

Connolly, Patrick J. Methow River studies: Preparing for mainstem stream restoration. Presentation for: Upper Columbia Regional Technical Team. March 2011, Wenatchee, Washington.

Connolly, Patrick J., Russell Perry, and Kyle D. Martens. Modeling fish movement, survival, and smolt production in a Methow River O. mykiss population. Workshop on Habitat and Fish Modeling. February 2011, Portland, Oregon.

Connolly, Patrick J., Kyle D. Martens, Michael A. Newsom, and Dana Weigel. Assessing the influence of habitat connectivity on success of different life history strategies for production of steelhead smolts. International Congress on the Biology of Fish. July 2010, Barcelona, Spain.

Connolly, Patrick J., Kyle D. Martens and Russell Perry. Assessing complex life cycles and stream restoration needs for steelhead using PIT tag technology and mark-recapture modeling. Western Division American Fisheries Society. April 2010, Salt Lake City, Utah.

Connolly, Patrick J., Kyle D. Martens, and Michael Newsom. Use of age structure and movement pattern information to help prioritize actions for restoring steelhead. Oregon Chapter American Fisheries Society. February 2010, Eugene, Oregon.

Ian G. Jezorek, Kyle D. Martens, and Patrick J. Connolly. Deployment and anchoring methods for instream PIT tag interrogation systems. Oregon Chapter American Fisheries Society, February 2010, Eugene, Oregon.

Connolly, Patrick J. Response of rainbow trout populations to reconnection with adult steelhead after removal of century-old barriers. Oregon Chapter American Fisheries Society, February 2009, Bend, Oregon.

Connolly, P.J., K.D. Martens, D.E. Weigel, and W.T. Tibbits. Effectiveness of actions in Beaver Creek. Upper Columbia Regional Technical Team 2010 analysis workshop synthesis report. February 2010, Wenatchee, Washington.

Connolly, Patrick J., Kyle D. Martens, and Wesley T. Tibbits. Following fish in the Methow River watershed. Town of Twisp, March 2009, Twisp, Washington.

Connolly, Patrick J. Environmental drivers of Oncorhynchus mykiss life history diversity. WashingtonOregon American Fisheries Society, April 2009, Shelton, Washington. 
Connolly, Patrick J., Kyle D. Martens, and Ian G. Jezorek. Contribution to steelhead smolt production from differing life history strategies: downstream movement as parr versus staying until time of smolting. Western Division American Fisheries Society, May 2009, Albuquerque, New Mexico.

\section{Posters to Date}

Connolly, Patrick J., Kyle D. Martens, and Wesley T. Tibbits. 2009. Effectiveness of rock type diversion structures for restoring upstream passage of juvenile and adult salmonids in Beaver Creek of the Methow River watershed. Poster presented at Western Division American Fisheries Society, May 2009, Albuquerque, New Mexico.

\section{Managing the database}

\section{Objective 6. Create and manage an electronic database of protocols used and data collected.}

Task 6.1. Enter data in a standard electronic format, and ensure high quality of data (QA/QC).

Progress in 2011: Data are currently being entered into Excel spreadsheets. After all date are entered, all data will be checked for error. PIT tag files are currently being entered and proofed. Once completed, they will be uploaded to PTAGIS. All fish and habitat data from prior years of this project (through 2010) were imported into Microsoft ${ }^{\circ}$ Office Access 2010 databases.

Task 6.2. Provide protocol and data inputs to the Integrated Status and Effectiveness Monitoring Project (ISEMP) in the effort to test the robustness of monitoring protocols, indicator metrics, and sampling designs currently used in monitoring programs.

Progress in 2011: We worked with ISEMP personnel to prepare our data and protocols so that they can be entered into ISEMP's database. We attended two meetings on the ISEMP database and it appears that our data will be easily adapted when they are ready. Many of our data have already been converted into the ISEMP format.

Task 6.3. Contribute and coordinate with the Pacific Northwest Aquatic Monitoring Partnership (PNAMP) in their effort to produce a comprehensive network of effective aquatic monitoring programs in the Pacific Northwest.

Progress in 2011: We regularly attended PNAMP meetings and kept up-to-date on all current PNAMP activities.

\section{References Cited}

Bureau of Reclamation. 2008. Methow Subbasin Geomorphic Assessment, Okanogan County, Washington Technical Appendices. Bureau of Reclamation Technical Service Center, Denver, Co, Pacific Northwest Regional Office, Boise, ID and Methow Field Station, Twisp, WA.

Connolly, Patrick J., and Kyle D. Martens. 2011. Mainstem Methow habitat effectiveness monitoring of stream restoration: Study Plan update for FY2011 and FY2012 Methow Study Plan 2009-2014: Updated for FY2011. USGS-Western Fisheries Research Center, Columbia River Research Laboratory. Cook, WA and Twisp, WA.

Water Quality Monitoring Technical Guide Book. 1999. The Oregon Plan for Salmon and Watersheds. http://www.oregon.gov/OWEB/docs/pubs/wq_mon_guide.pdf?ga=t. Pp. 6-1 to 6-12. 



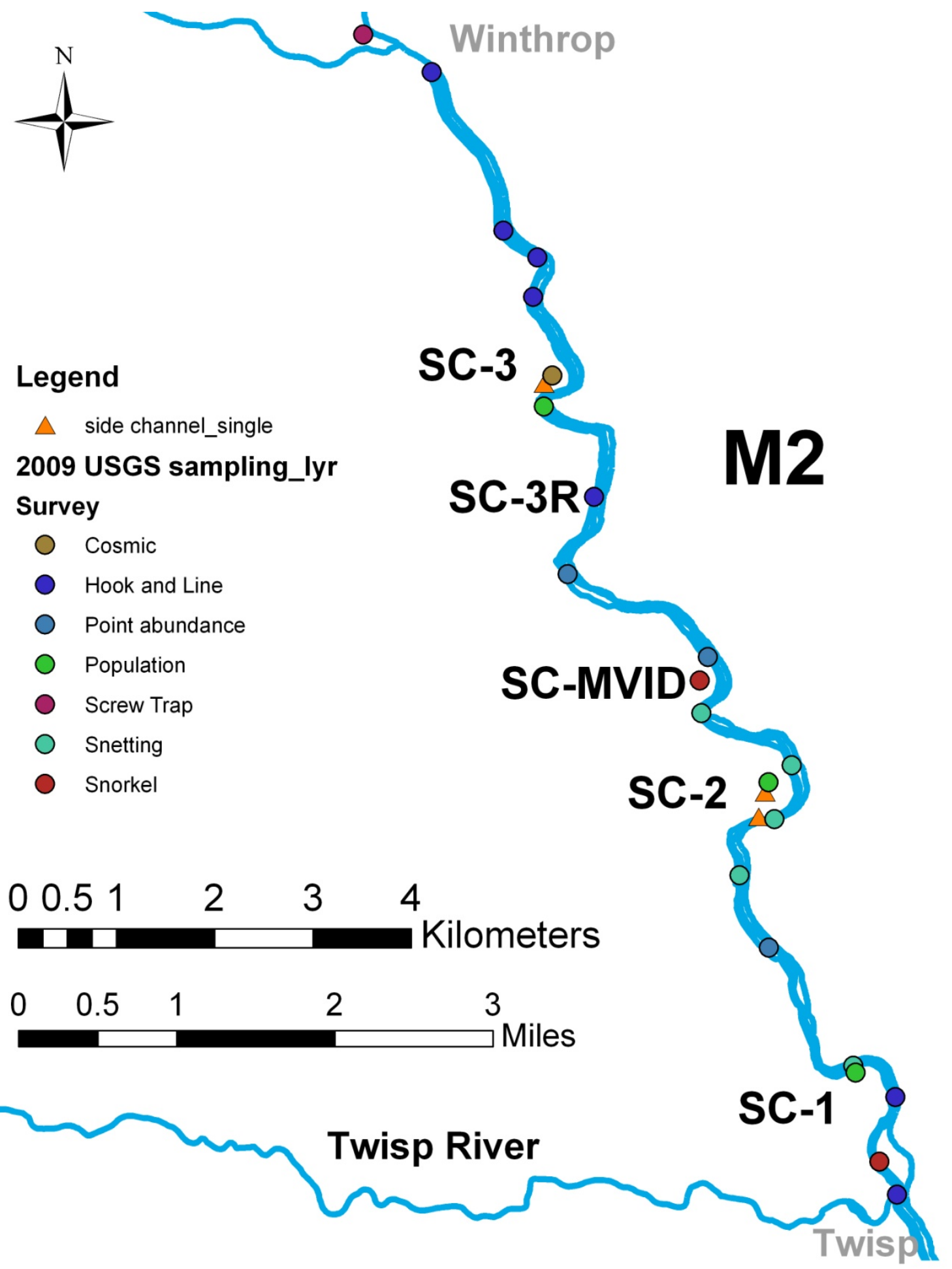

Figure 1. Map of the Middle Methow (M2) reach of the Methow River, Washington, showing the locations of passive integrated transporter (PIT) tag interrogation systems that are installed and maintained by the U.S. Geological Survey as of November 2011 and USGS sampling locations by types of surveys. 


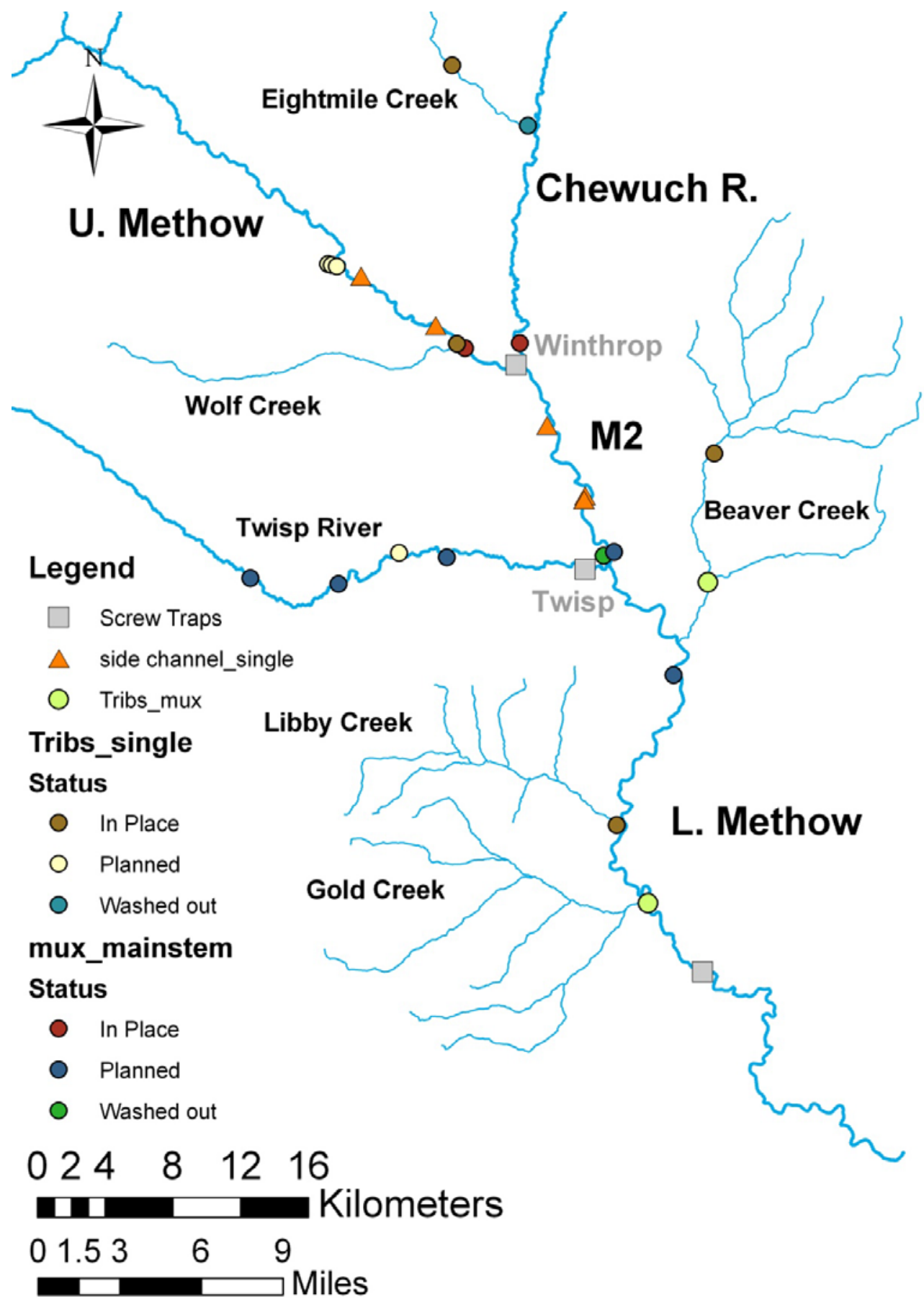

Figure 2. Map of study area in the Methow River showing the location and status of screw traps and various passive integrated transponder interrogation systems installed and maintained by the U.S. Geological Survey as of November 2011. Side channel_single = single antenna PIT tag interrogator located in side channels, Tribs_mux = Multiple antenna PIT tag interrogator located in tributaries of the Methow, Tribs_single $=$ Single antenna PIT tag interrogator located in tributaries of the Methow, and mux_maintstem = Multiple antenna PIT tag interrogator located in the mainstem Methow River. 


\section{Tables 1-4}

Microsoft@ Excel files of tables 1-4 are available at $h t t p: / / p u b s . u s g s . g o v / o f / 2012 / 1108$.

Table 1. Streams surveyed for fish and where a total of 5935 PIT tags were deployed in the Methow watershed during the 2011 field season.

Table 2. Streams surveyed or sampled for fish and where a total of 2101 genetic samples were collected in the Methow watershed during the 2011 field season.

Table 3 Current status of U.S. Geological Survey temperature loggers in the Methow River and its tributaries.

Table 4. Presence and absence of fish species sampled and/or observed in the Methow watershed by the U.S. Geological Survey during the 2011 field season. 
This page left intentionally blank 